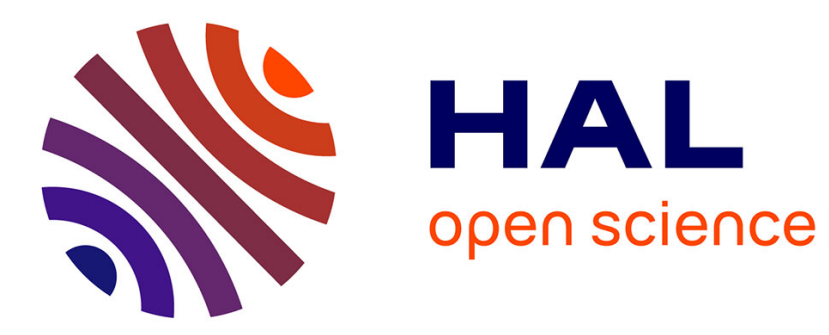

\title{
SPR Screening of Metal chelating Peptides in a Hydrolysate for their Antioxidant Properties
}

Laetitia Canabady-Rochelle, Katalin Selmeczi, Sabrina Collin, Andreea Pasc, Laurence Muhr, Sandrine Boschi-Muller

\section{- To cite this version:}

Laetitia Canabady-Rochelle, Katalin Selmeczi, Sabrina Collin, Andreea Pasc, Laurence Muhr, et al.. SPR Screening of Metal chelating Peptides in a Hydrolysate for their Antioxidant Properties: Abbreviated running tittle: Screening of antioxidant metal chelating peptides using SPR. Food Chemistry, 2018, 239, pp.478-485. 10.1016/j.foodchem.2017.06.116 . hal-03553196

\author{
HAL Id: hal-03553196 \\ https://hal.science/hal-03553196
}

Submitted on 2 Feb 2022

HAL is a multi-disciplinary open access archive for the deposit and dissemination of scientific research documents, whether they are published or not. The documents may come from teaching and research institutions in France or abroad, or from public or private research centers.
L'archive ouverte pluridisciplinaire HAL, est destinée au dépôt et à la diffusion de documents scientifiques de niveau recherche, publiés ou non, émanant des établissements d'enseignement et de recherche français ou étrangers, des laboratoires publics ou privés. 


\section{Hydrolysate for their Antioxidant Properties}

Laetitia L.S. CANABADY-ROCHELLE ${ }^{1 a^{*}}$, Katalin SELMECZI², Sabrina COLLIN ${ }^{3}$, Andreea PASC ${ }^{2}$, Laurence MUHR $^{1 \mathrm{~b}}$, and Sandrine BOSCHI-MULLER ${ }^{3}$

${ }^{1}$ Université de Lorraine, Laboratoire Réactions et Génie des Procédés (LRGP, UMR CNRS-UL 7274), aEquipe Bioprocédés-Biomolécules, ENSAIA, 2, avenue de la forêt de Haye, 54500 Vandoeuvre-lès0 Nancy, France, bEquipe Sols et Eaux, ENSIC, 1 rue Grandville, 54000 Nancy, France 2Université de Lorraine, Laboratoire Structure et Réactivité des Systèmes Moléculaires Complexes (SRSMC, UMR CNRS-UL 7565), Faculté des Sciences et Techniques, B.P. 70239, 54506 Vandoeuvre-lès-

${ }^{3}$ Université de Lorraine, Laboratoire Ingénierie Moléculaire et Physiopathologie Articulaire (IMoPA, UMR CNRS-UL 7365), Equipe Enzymologie Moléculaire et Structurale, Campus Biologie-Santé, Faculté de Médecine, 9, avenue de la forêt de Haye, CS 50184, 54505 Vandoeuvre-lès-Nancy, France

*Corresponding author:

Laetitia CANABADY-ROCHELLE

\section{Laetitia.canabady-rochelle@univ-lorraine.fr}

Université de Lorraine, Laboratoire Réactions et Génie des Procédés (LRGP, UMR CNRS-UL 7274),

Equipe Bioprocédés-Biomolécules, ENSAIA, 2, avenue de la forêt de Haye, 54500 Vandoeuvre-lès-

Nancy, France

Phone number: $00+33(0) 3.72 .74 .38 .86$.

Fax number: $00+33(0) 3.83 .59 .58 .24$. 


\section{Hydrolysate for their Antioxidant Properties}

Highlights.

- Metal chelating peptides were screened in protein hydrolysates using SPR.

- An apparent affinity constant and a maximal resonance can be determined with SPR.

- $K_{\mathrm{A}}$ should represent the proportion of metal binding peptides in the hydrolysate.

- A correlation was established between SPR-determined $K_{\mathrm{A}}$ and metal chelation tests.

\section{ABSTRACT}

There is a growing need in the industrial sector (health, nutrition and cosmetic) to discover new biomolecules with various physico-chemical and bioactive properties. Various beneficial effects of peptides - notably those produced from protein hydrolysis - are reported in the literature. The antioxidant activity involves various mechanisms, among them metal chelation, studied by UVvisible spectrophotometry. In this paper, we set up an original method of screening metal chelating peptides in a hydrolysate using Surface Plasmon Resonance (SPR) for their antioxidant properties. To date, the empirical approach used several cycles of hydrolysate fractionation and bioactivity evaluation until the isolation of the pure bioactive molecule and its identification. Besides, the detection of metal-chelating peptide is not sensitive enough by spectrophotometry. For the first time, metal chelating peptides were screened in hydrolysates using SPR and a correlation was established between affinity constant determined in SPR and metal chelation capacity determined from UV-visible spectrophotometry.

\section{INTRODUCTION}

Food protein-derived bioactive peptides (BPs) have been reported to trigger certain physiological responses in the body, thereby influencing health positively. Those peptides have attracted high 
research and consumer interest due to their huge potential in functional foods and other dietary intake to promote health. However, successful product development is limited by the fact that current manufacturing processes are either difficult to scale up, expensive, or may affect the structure-activity relations and thus the properties of those peptides.

The industrial sector (especially in health, nutrition and cosmetics) needs to discover new biomolecules presenting various physico-chemical or bioactive properties. Various beneficial effects of peptides are reported in the literature such as anti-hypertensive (Pihlanto-Leppälä, 2001; Marzak et al, 2003), anti-thrombosis (Ariyoshi, 1993), anti-carcinogeneous (Messina \& Messina, 1991), opioid (Zioudrou, Streaty \& Klee, 1979), anti-microbial (Broeckaert, Cammue, De Bolle, Thevissen, De Samblanx, \& Osborn, 1997), or growth factor for cell culture (Franek, Hohenwarter \& Katinger, 2000; Deparis et al, 2003; Farges-Haddani et al, 2006; Chabanon et al, 2008).

Peptides can be produced from enzymatic hydrolysis of proteins extracted from vegetable or animal co-products. Antioxidant peptides were already isolated from protein hydrolysate of various origins, notably from vegetable resources such as rapeseed proteins (Pan, Jiang \& Pan, 2011; Zhang, Wang, Xu \& Gao, 2009), chickpea (Zhang, Li, Miao \& Jiang, 2011), sweet potatoes (Zhang, Mu \& Sun, 2012), or lucerne (Xie, Huang, Xu, \& Jin, 2008).

Antioxidant capacity is a generic term, which recovers various chemical mechanisms. On total, about twenty antioxidant tests are reported in the literature (Huang, Ou \& Prior., 2005) and various complementary tests must be carried out to obtain a representative result of the whole antioxidant capacity of a given molecule.

Nevertheless, three main activities describe antioxidant power. The first one is the scavenging of various free radicals and involves either an electron transfer (ET) mechanism or a hydrogen atom transfer (HAT) mechanism. Radical scavenging activity is mainly followed by ABTS or DPPH tests, with $\mathrm{ABTS}^{\circ+}$ or $\mathrm{DPPH}^{\circ+}$ radicals, respectively. The second mechanism relies on the inhibition of lipid peroxidation (Farvin, Baron, Nielsen \& Jacobsen, 2010), which can be followed 
by oxygen consumption or MalonDiAldehyde test. Finally, metal chelation such as iron or copper ions complexation (Decker \& Welch, 1990; Xie et al, 2008) is often studied as an indirect antioxidant mechanism since upon metal complexation, radical reactions in chain are inhibited and oxidation phenomena are delayed. Indeed, in living systems, the presence of transient metal ion, such as $\mathrm{Fe}^{2+}$ and $\mathrm{Cu}^{2+}$ involve the formation of Reactive Oxygen Species (ROS) as for instance, hydroxyl radicals $\left(\mathrm{OH}^{\circ}\right)$ formed by the Fenton reaction. In addition, ferrous ions $\left(\mathrm{Fe}^{2+}\right)$ can catalyse the formation of hydroxyl radicals via the Haber-Weiss reaction, which occurs in the presence of superoxide anions. These free radicals, produced locally, can react with adjacent biomolecules and are responsible of serious damages in the biological tissue. Due to some environmental conditions (i.e. pollution, UV, non-equilibrated food), defence mechanisms involving antioxidants are sometimes overcome; an oxidant stress is generated, which can lead to the development of several pathologies in humans such as diabetes, rheumatoid arthritis, and cancer (Abuja \& Albertini, 2001; Collins, 2005; Halliwell, 2000; Halliwell \& Whiteman, 2004; Hoelzl, Bichler, Ferk, Simic, Nersesyan, \& Elbling, 2005).

Yet, the low concentration of target bioactive peptides in an hydrolysate (a complex mixture of peptides sequences) and the difficulty to associate their bioactivity to one or several specific physicochemical properties constitute one of the main factors limiting their separation and their use. To valorise these bioactive peptides, one of the principal stakes is then the separation of peptides in a complex mixture, according to the desired bioactivity. The empirical approach consists in separating each hydrolysate in various fractions and in evaluating their bioactivity. These sequential steps are reiterated until reaching pure bioactive molecules identified by mass spectrometry. To date, the separation methods settled up (i.e. chromatography, ultrafiltration) are time-consuming. Besides, depending on the size of the peptide of interest, and its low concentration in the hydrolysate - whether present -, a detection using UV-visible spectrophotometry is often not sensitive enough. 
Surface Plasmon Resonance (SPR) enables the monitoring of molecular interactions in real time.

102 Its main advantage is the label free detection based on the phenomenon of surface plasmon resonance. While the interacting molecule (ligand) is immobilized on the surface of a sensor chip, the analyte is injected in solution and flow over the surface. The binding of the analyte to the immobilized ligand involves alteration of the refractive index at the sensor surface, which is proportional to the change in mass concentration. From sensorgram (SPR response in resonance unit plotted against time) studied at various analyte concentrations, the affinity constant of the analyte for the ligand can be determined.

Several studies reported the use of SPR for the affinity comparison of different tagged proteins to metal ions (Nieba et al, 1997; Bernaudat \& Bülow, 2005; Kurzatkowska et al, 2014). Yet, Knecht et al, (2009) were the only ones to study the affinity of His-tag peptides to $\mathrm{Ni}^{2+}$ ions.

Hence, a direct screening of metal chelating peptides using SPR would enable to detect more rapidly their presence in a hydrolysate before launching a separation phase, that should be engaged solely in the case of positive bioactivity screening. To the author's knowledge, SPR has never been used as a screening method of metal chelating peptides related to their antioxidant capacities.

The aim of this study is to propose a new proof-of-methodology on a screening procedure of metal chelating peptides in hydrolysates for their antioxidant properties. Such approach uses SPR with a $\mathrm{M}^{2+}$-NTA sensor chip. The main advantage of such technique is based on the higher sensitivity and label free detection of SPR detector as compared to classical UV-Vis spectrometry. Thanks to this methodology, the most interesting sources of hydrolysates in terms of metal chelating peptides could be screened rapidly. Moreover, another aim of this study is to correlate affinity constant determined by SPR methodology and antioxidant chemical tests based on metal chelation using UV-visible spectrophotometry.

To overcome potential interferences of non-peptide contaminants with SPR, the SPR methodology was first set up on one hydrolysate, taken as a model, with or without purification. 
Once the methodology validated, screening was carried out on raw samples for further industrial applications. Then, correlation was established between affinity constants and metal chelation capacities determined on raw hydrolysates.

\section{MATERIALS AND METHODS}

\subsection{Hydrolysates}

\subsubsection{Industrial specification}

Peptide hydrolysates were provided from Kerry group (Ingredients and Flavours Department, USA). They were obtained from various vegetable sources such as soy (i.e. H1510, H1512, and UP Soy), wheat (H4601N) and rice proteins (H5603). The total and free amino acids composition is given in the industrial specification (Supplementary data, Table SD 1). Besides, for each hydrolysate, the global amino acid composition was presented by class of amino acids, with its main characteristics in terms of total nitrogen ( $\mathrm{TN}, \%)$, protein and degree of hydrolysis (Supplementary data, Table SD 2).

\subsubsection{OPA quantification}

As complex mixture of peptides, hydrolysates cannot be determined in molar concentration. To compare them, peptide concentration was quantified using ortho-phthaldialdehyde test (OPA) and expressed in $\mathrm{mM}$ glycine equivalent. This spectrophotometric dosage involves a reaction between the N-terminal extremity of each peptide present in the mixture and OPA reagent (OPA; ThermoFisher Scientific, Loughborough, UK) in the presence of N,N-dimethyl-2-mercaptoethylammonium (ThermoFisher Scientific). The chemical group obtained absorbs at a wavelength of $340 \mathrm{~nm}$. 
149 The OPA quantification was performed according to Frister, Meisel, \& Schlimme (1988). The

150 OPA solution was prepared by dissolving $40 \mathrm{mg}$ of OPA in $1 \mathrm{~mL}$ of pure methanol and $100 \mathrm{mg}$ of N,N-dimethyl-2-mercaptoethyl ammonium in a few milliliters of Borax buffer (sodium tetraborate $100 \mathrm{mM}, 1 \% \mathrm{w} / \mathrm{v}$ sodium dodecyl sulfate, $\mathrm{pH}$ 9.3, Sigma-Aldrich). These two solutions were mixed in a $50 \mathrm{~mL}$-volumetric flask, qsf Borax buffer. The molar concentration of $1 \mathrm{mg} \cdot \mathrm{mL}^{-1}$ peptide hydrolysate solutions $(20 \mu \mathrm{L})$ qsf Borax buffer was measured in 96-well plate by spectrophotometry at $340 \mathrm{~nm}$ after 3 min incubation with stirring at room temperature (ThermoFisher Scientific) with the OPA solution $(200 \mu \mathrm{L})$. For each hydrolysate, molar concentration (expressed in equivalent $\alpha-\mathrm{NH}_{2}$ ) was determined using a calibration curve performed with glycine.

\subsubsection{Determination of total phenolics}

The total content of phenolic compounds was quantified by the method of Folin-Ciocalteu according to the colorimetric method described by Singleton \& Rossi (1965) and adapted to a 96well microplate by Mussato, Ballesteros, Martins \& Teixeira (2011). Briefly, $5 \mu \mathrm{L}$ of an hydrolysate solution $\left(25\right.$ g. $\left.\mathrm{L}^{-1}\right)$ were mixed with $60 \mu \mathrm{L}$ of sodium carbonate solution at $7.5 \%$ (w/v) and $15 \mu \mathrm{L}$ of Folin-Ciocalteu reagent (1N; Sigma Aldrich). Then, $200 \mu \mathrm{L}$ of ultrapure water $\left(18 \mathrm{~m} \Omega \cdot \mathrm{cm}^{-1}\right)$ were added and the solutions were mixed. Samples were incubated at $60^{\circ} \mathrm{C}$ for $5 \mathrm{~min}$ and cooled down at room temperature. Absorbance was measured at $700 \mathrm{~nm}$ using a microplate reader. Calibration of this test was carried out with gallic acid standard solutions $(0$, 200, 400, 600, 1000 et 1500 mg. $\left.\mathrm{L}^{-1}\right)$ and the blank was performed with ultrapure water. The total content of phenolic compounds was expressed in mass percentage of hydrolysate powder $(\mathrm{w} / \mathrm{w})$. 


\subsubsection{Purification of hydrolysates}

174 Samples were purified using Solid Phase Extraction column (CC6 polyamide column,

175 Chromabonb PA $6 \mathrm{~mL} / 1000 \mathrm{~g}$, Macherey-Nagel, Duren, Germany) to remove polyphenols.

176 Purification step was adapted from Collins, Ng, Fong, Wan, \& Yeung, (1998). Briefly, the column

177 was conditioned with $2 \times 5 \mathrm{~mL}$ of ultrapure water, removed upon centrifugation (1000 g, $1 \mathrm{~min})$.

178 Then, $5 \mathrm{~mL}$ of hydrolysate solution $\left(25 \mathrm{~g} \cdot \mathrm{L}^{-1}\right)$ was deposited onto the column and percolated at

179 atmospheric pressure. The peptide fraction was eluted with $5 \mathrm{~mL}$ water and the column was then

180 successively eluted with $5 \mathrm{~mL} \mathrm{MeOH} 50 \%, 5 \mathrm{~mL}$ of pure $\mathrm{MeOH}$ and several washes of $0.1 \mathrm{M}$

$181 \mathrm{NaOH}$. The peptide fraction was then lyophilized and frozen until analysis.

\subsection{Metal chelation tests}

The antioxidant capacity determined by $\mathrm{Cu}^{2+}$ chelation was measured by spectrophotometry using murexide as colored indicator. A mini-review on metal chelation tests used in the literature and their experimental conditions is presented in supplementary data (Table SD3). This test was adapted from literature (Wu, Shiau, Chen, \& Chiou, 2003; Wong, Leong \& Koh, 2006 and Li, Wang, Chen \& Chen, 2011). Absorbance was measured at two wavelengths, $485 \mathrm{~nm}$ and $520 \mathrm{~nm}$, for the copper-murexide complex and the murexide alone, respectively. The ratio of absorbance $190\left(\mathrm{~A}_{485} / \mathrm{A}_{520}\right)$ was considered proportional to the free copper ion $\left(\mathrm{Cu}^{2+}\right)$ concentration (Barges, Cravotto, Gianolio \& Fedeli, 2006).

This test was adapted for the microplate study to reduce the time of experiments and the volume of studied solution. EDTA (EDTA disodium salt dihydrate, Fluka Chemie, Buchs, Switzerland) and carnosine (99\%, Sigma Aldrich), both studied as positive controls, were prepared in hexamine buffer (10 mM Hexamine, $10 \mathrm{mM} \mathrm{KCl}, \mathrm{pH}$ 5) first in a range of concentration $0-40$ $\mathrm{mM}$ to determine saturation, then in the range $0-4 \mathrm{mM}$ for linearization. Peptide hydrolysates were prepared similarly in a concentration range varying between $0-40$ g. $\mathrm{L}^{-1}$, concentration then 
expressed in $\mathrm{mM}$ equivalent glycine. Experiment was repeated 5 times. Each sample (EDTA, carnosine and hydrolysate solutions) was directly diluted in microplate with hexamine buffer for a total volume of $143 \mu \mathrm{L}$. Then, $143 \mu \mathrm{L}$ of a $3 \mathrm{mM} \mathrm{CuSO}$ solution prepared in hexamine buffer and $14 \mu \mathrm{L}$ of $1 \mathrm{mM}$ murexide solution were added in each well (total volume: $300 \mu \mathrm{L}$ ). The 96well plate was incubated for 3 min at ambient temperature and absorbance measured at $485 \mathrm{~nm}$ and $520 \mathrm{~nm}$. For each sample, the $\mathrm{Cu}^{2+}$ chelation capacity was determined according to equation (3):

$\mathrm{Cu}^{2+}$ complexation $(\%)=\frac{\left[\left(\mathrm{A}_{485} / \mathrm{A}_{520}\right)_{0-}\left(\mathrm{A}_{485} / \mathrm{A}_{520}\right)_{\mathrm{s}}\right]}{\left(\mathrm{A}_{485} / \mathrm{A}_{520}\right)_{0}} \times 100$

With $\left(\mathrm{A}_{485} / \mathrm{A}_{520}\right)_{0}=$ ratio of absorbances measured in the absence of sample (negative control: hexamine buffer),

And $\left(\mathrm{A}_{485} / \mathrm{A}_{520}\right)_{\mathrm{s}}=$ ratio of absorbances measured in the presence of sample (EDTA, carnosine or hydrolysate).

For each sample, a linearization was performed in the linear part of the curve in order to determine, after calculation, the indices characterizing its capacity for $\mathrm{Cu}^{2+}$ chelation: the EECC (EDTA Equivalent copper Chelation Capacity) or the CECC (Carnosine Equivalent copper Chelation Capacity). Such indices are calculated according to equations (4) and (5):

$$
\begin{aligned}
& E E C C=\frac{a_{S}}{a_{E D T A}}(4) \\
& C E C C=\frac{a_{S}}{a_{C a r}}
\end{aligned}
$$

With $a_{s}=$ the slope of the linearization line, for hydrolysate $(\%$ of copper chelated as a function of peptide concentration).

$\mathrm{a}_{\mathrm{EDTA}}=$ the slope of the linearization line for EDTA $\%$ of copper chelated as a function of EDTA concentration). 
$a_{c a r}=$ the slope of the linearization line for carnosine $(\%$ of copper chelated as a function of

222 carnosine concentration).

\subsection{Affinity constant determination}

225

Binding of peptides present in hydrolysate to $\mathrm{Ni}^{2+}$-NTA was analysed by Surface Plasmon Resonance (SPR). The SPR measurement was performed on a Biacore X100 instrument (Biacore AB, Uppsala, Sweden) equipped with NTA (nitrilotriacetic acid) sensor chips at $25^{\circ} \mathrm{C}$. The method was adapted according to Knecht et al (2009) with slight modification on tri-histidine peptide $(\mathrm{HHH})$ before the study of peptide hydrolysate.

The eluent buffer (PBS 1X, pH 7.4) and the dispenser buffer (PBS 1X, pH 7.4, 0.005\% Tween 20) were filtered $(0.22 \mu \mathrm{m}$, support membrane, low protein binding, non pyrogenic, PALL) and degassed by the Biacore instrument. The PBS 1X running buffer was prepared from a 10X concentrate made of $67 \mathrm{mM} \mathrm{Na}_{2} \mathrm{HPO}_{4} .2 \mathrm{H}_{2} \mathrm{O}, 12.5 \mathrm{mM} \mathrm{KH}_{2} \mathrm{PO}_{4}, 150 \mathrm{mM} \mathrm{NaCl}$ with a $\mathrm{pH}$ value of 6.65. When the 10X stock solution was diluted to $1 \mathrm{X}$, the final $\mathrm{pH}$ of PBS $1 \mathrm{X}$ was of 7.4.

Peptide hydrolysates were dissolved at various concentrations in freshly prepared PBS 1X buffer before each experiment. Loading of $\mathrm{Ni}^{2+}$ onto the NTA chip was performed with a $\mathrm{NiCl}_{2}$ solution $(500 \mu \mathrm{M}$, Biacore kit, Uppsala, Sweden) and the chip surface was regenerated with imidazole $(500 \mathrm{mM})$ dissolved in ultrapure water $\left(18.2 \mathrm{~m} \Omega \cdot \mathrm{cm}^{-1}\right)$, followed by a regeneration solution $(10 \mathrm{~mL}$ buffer added with $87 \mu \mathrm{L}$ EDTA at $50 \mu \mathrm{M})$.

All binding experiments were performed at a flow rate of $20 \mu \mathrm{L} \cdot \mathrm{min}^{-1}$, starting with a 1 -min injection of aqueous $\mathrm{NiCl}_{2}$ solution to load the NTA chip, with a 1-min stabilisation period. A NTA flow cell without $\mathrm{Ni}^{2+}$ was used as a reference cell. Then each studied peptide hydrolysate was injected on both flow path for $270 \mathrm{~s}$ followed by $270 \mathrm{~s}$ of undisturbed dissociation time. The regeneration procedure consisted of 1 -min injections of imidazole $(500 \mathrm{mM})$ at $20 \mu \mathrm{L} \cdot \mathrm{min}^{-1}$ 
followed by an extra-wash with buffer-EDTA $(50 \mu \mathrm{M})$. Upon the second regeneration procedure, the surface was washed with SDS $0.5 \% \mathrm{v} / \mathrm{v}$ for $1 \mathrm{~min}$ at a flow rate of $40 \mu \mathrm{L} \cdot \mathrm{min}^{-1}$ followed by an extra-wash after injection with running buffer. Each regeneration and washing cycle was repeated twice. One buffer blank before and between each sample series were used for double referencing during data processing (Myszka, 1999; mentioned in: Knecht et al, 2009).

The sensorgrams obtained from the SPR experiments were processed with BIAevaluate software. The isotherms obtained were expressed in Resonance Unit (RU, corrected by the offset value) as a function of the concentration of peptide hydrolysate (expression in $\mathrm{mM}$ equivalent glycine according to the OPA quantification). The dissociation constants ( $K_{\mathrm{D}}, \mathrm{M}$ equivalent glycine) were determined at equilibrium by fitting the experimental data with the 1:1 binding model. The affinity constant $\left(K_{\mathrm{A}}, \mathrm{M}^{-1}\right.$ equivalent glycine) was calculated as the inverse of the dissociation constant.

\section{RESULTS AND DISCUSSION}

\subsection{Hydrolysate characterization}

\subsubsection{Raw hydrolysates}

Hydrolysates are composed of a mixture of peptides, whose sequences are unknown. For their comparison, peptide concentration of hydrolysates solutions $\left(1 \mathrm{mg} \cdot \mathrm{mL}^{-1}\right)$ were quantified using OPA test in order to express their molar concentration in $\mathrm{mM}$ equivalent glycine. For raw hydrolysates, peptide concentration varied between 1.23 and $1.82 \mathrm{mM}$ equivalent glycine (Table 1).

According to their specification, industrial hydrolysates have been submitted to ultrafiltration, the method commonly used to remove polyphenols (Bornman, Gokemen and Nyhuis, 2001; 
Gokmen, Acar \& Karahman, 2003). Thus, raw hydrolysates were supposed to be free of polyphenols. Surprisingly, total polyphenols were quantified between 3.6\% (w/w) for H1510 and H1512 hydrolysates up to $5.9 \%$ (w/w) for H5603 (Table 1). The fact that similar value was observed for a trypsin casein hydrolysate used as a negative control $(5.3 \pm 0.2 \% \mathrm{w} / \mathrm{w})$ suggests the existence of interferences in quantification method due for example to tyrosine residues in relation with their phenol group, but the presence of residual polyphenols in hydrolysates can not be rule out.

\subsubsection{Purified hydrolysates}

The purification method adapted from Collins et al (1998) was carried out on polyamide resins to eliminate non-peptides contaminants such as polyphenols. After a purification step, peptide concentration of hydrolysate samples was not significantly modified on the whole as proved by OPA quantifications (Table 1). In the meantime, there was practically no loss of total polyphenols. Nevertheless, as observed in Collins et al (1998), a significant amount of binding was seen as a brown coloration of resin, which eluted with sodium hydroxide (result not shown). Besides, the comparison of the OPA quantification test carried out on raw hydrolysate powder (1g.. $\left.\mathrm{L}^{-1}\right)$ and on a powder of hydrolysate purified onto CC6 polyamide column, lyophilised and then reconstituted (1g. $\left.\mathrm{L}^{-1}\right)$ showed a slight increase in peptide concentration (see Supplementary data. Figure SD1.).

\subsection{Determination of metal chelating capacity/affinity by SPR}

\subsubsection{Set up of SPR method on purified H5603 hydrolysate}

Validation of the SPR method has been realised on the H5603 hydrolysate as a model, and in order to overcome potential interferences, in a first approach, hydrolysate purified on CC6 polyamide column was used. The initial methodology set up on $\mathrm{HHH}$ peptide by Knecht et al. 
(2009) was adapted for the study of hydrolysate. Binding to $\mathrm{Ni}^{2+}$-NTA was analyzed both qualitatively and quantitatively with surface plasmon resonance (SPR) using commercially available NTA sensor chips from Biacore. Purified H5603 hydrolysate was injected at a concentration varying from 0 to $40 \mathrm{~g} . \mathrm{L}^{-1}$ for $4.5 \mathrm{~min}$ at a flow rate of $20 \mu \mathrm{L} \cdot \mathrm{min}^{-1}$ to detect the association phase, followed by a dissociation time of $4.5 \mathrm{~min}$ at a flow rate of $20 \mu \mathrm{L} \cdot \mathrm{min}^{-1}$. This led to a clear detection of binding signals for all tested concentrations of hydrolysate with very fast association, reaching equilibrium immediately after injection, and dissociation rates, and with an excellent reproducibility of the triplicate injections (not shown) (Figure 1). Association and dissociation phases were shown to occur in a dose-dependent manner, suggesting the existence of an apparent affinity of the hydrolysate (peptides) for $\mathrm{Ni}^{2+}$. The hyperbolic profile of the level of binding at equilibrium as a function of the sample concentration showed a saturating behaviour, suggesting the formation of peptide- $\mathrm{Ni}^{2+}$ complexes.

The experimental isotherm, i.e. the level of binding expressed in Resonance Unit (RU) in function of hydrolysate concentration expressed in $\mathrm{mM}$ equivalent glycine according to the $\mathrm{NH}_{2}$ terminal concentration quantified using OPA test, was fit to the 1:1 binding model using BIAevalution (version 2) software (Figure 1). It enabled to determine the value of the apparent dissociation constant $\left(K_{\mathrm{D}}\right)$, the maximal signal $\left(\mathrm{R}_{\max }\right)$ at saturation of the $\mathrm{Ni}^{2+}$-NTA chip and the offset. The offset value (expressed in RU), which represents the difference in response between the reference (no $\mathrm{Ni}^{2+}$ ) and the sample canal (with $\mathrm{Ni}^{2+}$ ) of the chip, was used to calculate the true maximal response $\left(\mathrm{R}_{\operatorname{maxc}}\right)$. From the value of the $K_{\mathrm{D}}$, the value of the apparent affinity constant $\left(K_{\mathrm{A}}\right)$ was calculated (Table 2). The lowest the $K_{\mathrm{D}}$ value, the highest the affinity of metal chelating peptides 313 for $\mathrm{Ni}^{2+}$ ions. Due to heterogeneity of the hydrolysate, in terms of peptide sequences and concentration of metal chelating peptides, it may be assumed that the value of the $K_{\mathrm{A}}$ should represent the proportion of metal binding peptides within the hydrolysate, whereas the value of the $\mathrm{R}_{\operatorname{maxc}}$ would be more representative of the size of the formed complexes. Thus, the results 
317 show that metal binding capacity of a hydrolysate can be quantified on purified peptide hydrolysate using Surface Plasmon Resonance.

319 In an industrial perspective, for screening various hydrolysates for their metal chelating peptides, metal-chelating properties should directly be explored on raw hydrolysates. Indeed, SPR experiments were performed similarly than previously on raw H5603 hydrolysate. The fact that similar values of $K_{\mathrm{A}}$ and $\mathrm{R}_{\operatorname{maxc}}$ were obtained for the purified and non-purified H5603 hydrolysate (Figure 2, Table 2) shows that metal binding capacity can be determined directly on raw hydrolysate using Surface Plasmon Resonance.

\subsubsection{Affinity constant determination on raw hydrolysates}

In order to set up a direct screening method of metal chelating peptide in complex mixture, raw hydrolysates constitute the most appropriate materials. Hence, SPR experiments were performed similarly than previously on H1510, H1512, H4601N and UP Soy raw hydrolysates.

For all hydrolysates, association and dissociation phases were shown to occur in a concentration dependent manner (Results not shown). Plots of response at equilibrium in function of hydrolysate concentration present a hyperbolic profile, whatever the hydrolysate (Figure 2). From the fitting of these experimental binding isotherms, values of the different parameters were obtained (Table 2). Considering the $K_{\mathrm{A}}$ values, the apparent affinity of raw peptide hydrolysate for $\mathrm{Ni}^{2+}$ ions varied according to the samples studied and evolved in the following rank: $\mathrm{H} 1512<$ H5603 < H4601N < UP Soy < H1510. The highest affinities were measured for the H1510 hydrolysate and then for UP Soy in comparison to the other three hydrolysates. 


\subsection{Metal chelation}

343 Metal chelation tests are usually performed on hydrolysate using spectrophotometric tests. A

344 mini-review on metal chelation tests used in the literature and their experimental conditions is

345 presented in supplementary data (Table SD3). Nevertheless, according to the size of the peptides

346 of interest, and their low concentration in the hydrolysate - whether present -, a detection using

347 UV-visible spectrophotometry may be sometimes not sensitive enough for such application.

The test of metal chelation capacity $\left(\mathrm{Cu}^{2+}\right)$ was validated on EDTA and carnosine using UVvisible spectrophotometry (Figure 3, panels $\mathbf{A}$ and $\mathbf{B}$ ) and then, tested on raw hydrolysates (Figure 3, panels $\mathbf{C}$ and D). The $\mathrm{Cu}^{2+}$ chelation capacity (\%) was plotted as a function of molar ratio (mM carnosine or EDTA $/ \mathrm{mM} \mathrm{CuSO}_{4}$ ) (Figure 3, panels A and B). Saturation was observed at $87 \%$ of $\mathrm{Cu}^{2+}$ chelated for EDTA and $82 \%$ for carnosine. Since EDTA is known as a really good complexing agent, the totality of $\mathrm{Cu}^{2+}$ is considered fully chelated for a calculation corresponding to $87 \%$ chelation capacity. For a $1: 1$ stoichiometry between EDTA and $\mathrm{Cu}^{2+}$, the copper chelated was of $62 \%$. For a $1: 1$ stoichiometry between carnosine and $\mathrm{Cu}^{2+}$, the copper chelated was about 30\%. In comparison of the study of Wu and co-workers (2003), these authors determined the chelating ability of a 4 mM-EDTA solution at $68 \%$ and the chelating effect of a 5 mM-carnosine solution at $32 \%$.

The $\mathrm{M}^{2+}$ chelation capacities (\%) were plotted as a function of the molar ratio of the hydrolysate over the metal concentration ( $\mathrm{mM}$ equivalent glycine / $\mathrm{mM} \mathrm{CuSO}_{4}$; Figure 3, panels $\mathbf{C}$ and $\mathbf{D}$ ). In Figure 3 (panels C), a Langmuir-shaped isotherm was observed for all the hydrolysates studied with saturation at about $80 \%$ copper chelation, which fit to the totality of the copper complexed as for positive controls (EDTA and carnosine). Nevertheless, as a complex mixture of peptides, all the peptides present in the hydrolysate are not able to complex the $\mathrm{Cu}^{2+}$ ions. In such conditions and despite the Langmuir-shaped isotherm, we cannot be sure that the binding of metal chelating peptides with metal ions can be approximated with a 1:1 model. Then, to 
determine, the most interesting source of hydrolysate in terms of metal chelating peptides, an indice expressed in equivalent chelation capacity (ECC) was calculated, considering either EDTA (EECC) or carnosine (CECC) as reference (part 2.2.), using the slope of the linear part of the curve (Table 2). Whatever the reference was, the rank remained the same: H1510 > UP Soy > H5603 > H1512 > H4601N. The variations between hydrolysates observed by UV spectrophotometry is less pronounced than those observed by SPR, when we compare respectively the results of metal chelation indices and the affinity constants, which seems to confirm once more the interest of SPR for the screening of metal chelating peptides in hydrolysates.

According to the literature, amino acids preferentially involved in metal chelation are known. A mini-review on amino acids and their functional groups involved in metal chelation is presented in supplementary data (Table SD4). Several amino acids are concerned especially (1) aspartic and glutamic acid, through their carboxylate function, (2) histidine via the imidazole ring, (3) arginine and lysine through the amino group, (4) cysteine with its thiol group (5) serine and threonine with hydroxyl. Nevertheless, over the five studied hydrolysates, relationship between the copper chelation capacity $(\%)$ and the given industrial amino acid composition cannot be stated (See SD1. Amino acid composition given in the industrial specification (SD2. Global amino acid composition and main characteristics of the hydrolysate).

\subsection{Correlations between affinity constants and metal chelation tests}

From the former data, the relation between the affinity constants $\left(K_{\mathrm{A}}, \mathrm{M}^{-1}\right)$ and the copper chelation indices was plotted (Figure 4, panels A and B, for EECC and CECC, respectively). A satisfactorily correlation was observed with a $\mathrm{R}^{2}$ value of 0.88 . Hence, in addition to the determination of $K_{\mathrm{A}}$ for peptide hydrolysate, SPR methodology can be used for the screening method of metal chelating peptides in a protein hydrolysate with more accuracy than the classical 
spectrophotometric method used to date. Nevertheless, no correlation was established between affinity constant and the amino acid content in each hydrolysate given in industrial specifications (see supplementary data SD1 and SD2). This could be due to the fact that the amino acid residue content is not the only factor involved upon the mechanism of complexation occurring between peptide and metal ion. Indeed, the position of one amino acid residue to another one is also important in the complexation mechanism. Hence as perspective of this work, SPR experiments will be coupled to Mass Spectrometry (SPR-MS), which could help us to establish correlations between affinity and amino acid composition in regards of the peptides sequence. Such study could be extended to model peptides of known sequence to better understand the link between affinity constant and peptide concentration.

\section{CONCLUSION}

Surface Plasmon Resonance is a powerful tool to screen antioxidant metal chelating peptides in hydrolysate before launching time-consuming separation. Besides, SPR can directly be used on industrial hydrolysates formerly treated by ultrafiltration without an additional step of purification. A good correlation was obtained between $K_{\mathrm{A}}$ and metal chelation capacity, when both analyses were carried out on raw industrial hydrolysates. According to the results of this study, SPR is an innovative method that can be used for screening various sources of hydrolysates in terms of metal chelating peptides and could be considered for various industrial applications such as nutraceutics or cosmetics.

Acknowledgements. This work was supported in part by CNRS, Université de Lorraine and the Fédération de Recherche 3209 CNRS-UL. The access to Biacore X100 (Service Commun de Biophysicochimie des Interactions, FR3209) was deeply appreciated. The authors would like to 
416 thank Kerry group for supplying raw hydrolysates. Laetitia Canabady-Rochelle thanks Emeline 417 Boyer, Tania Djehel and Nesrin Loulou for their technical assistance.

418 
Abuja, P., \& Albertini, R. (2001). Methods for monitoring oxidative stress, lipid peroxidation and oxidation resistance of lipoproteins. Clinica Chimica Acta, 306, 1-17.

Ariyoshy, Y. (1993). Angiotensin-converting enzyme-inhibitors derived from food proteins. Trends in Food Science \& Technology, 4(5), 139-144.

Barges A., Cravotto G., Gianolio E., \& Fedeli F. (2006). How to determine free Gd and free ligand in solution of Gd chelates. A technical note. Contrast Media and Molecular Imaging, 1, 184-188.

Bernaudat F. \& Bülow L. (2005). Rapid evaluation of nickel binding properties of His-tagged lactate dehydrogenases using surface plasmon resonance. Journal of Chromatography A, 1066, 219-224.

Borneman Z., Gokemen V., and Nyhuis H.H. (2001) Selective removal of polyphenols and brown color in apple juice using PES/PVP membranes in a single ultrafiltration process. Separation and Purification Technology, 22-3, 53-61.

Broeckaert W.F., Cammue B.P.A, De Bolle M.F.C, Thevissen K., De Samblanx G.W., Osborn R.W. (1997). Antimicrobial peptides from plant. Critical Review in Plant Science, 16(3): 297-323.

Chabanon G., Alves da Costa L., Farges B., Harscoat C., Chenu S., Goergen J.L., Marc A., Marc I., Chevalot I. (2008). Influence of the rapeseed protein hydrolysis process on CHO cell growth. Bioresourource Technology, 99: 7143-7151.

Collins, A. (2005). Antioxidant intervention as a route to cancer prevention. European. Journal of Cancer, 41, 1923-1930.

Collins R.A., Ng T.B., Fong W.P., Wan C.C. and Yeung H.W. (1998). Removal of polyphenolic compounds from aqueous plant extracts using polyamide minicolumns. Biochemistry and Molecular Biology International, 45(4): 791-796. 
Decker, E.A. \& Welch, B. (1990). Role of ferritin as a lipid oxidation catalyst in muscle food. Journal of Agricultural and Food Chemistry, 38, 674-677.

Deparis V., Durrieu C., Schweizer M., Marc I., Goergen J.L., Chevalot I. \& Marc A. (2003). Promoting effect of rapesseed proteins and peptides on Sf9 insect cell growth. Cytotechnology, 42:75-85.

Farges-Haddani B., B. Tessier, S. Chenu, I. Chevalot, C. Harscoat, I. Marc, J.L. Goergen, \& A. Marc. (2006). Peptides fractions of rapeseed hydrolysates as an alternative to animal proteins in CHO cell culture media. Process Biochemistry, 41: 2297-2304.

Farvin K.H.S., Baron C.P., Nielsen N.S. \& Jacobsen C. (2010). Antioxidant activity of yoghurt peptides: Part 1-in vitro assays and evaluation in w3 enriched milk. Food Chemistry, 123: 10811089.

Franek F., Hohenwarter O., \& Katinger H. (2000). Plant protein hydrolysates: Preparation of defined peptide fractions promoting growth and production in animal cells cultures. Biotechnoogy. Progress, Sept-Oct,16(5): 688-692.

Frister, H., Meisel, H., \& Schlimme E. (1988). OPA method modified by use of N,N-dimethyl2-mercaptoethylammonium chloride as thiol component. Fresenius' Journal of Analytical Chemistry, 330, 631-633.

Gokmen V., Acar J., and Karahman N. (2003) Influence of conventional clarification and ultrafiltration on the phenolic composition of golden delicious apple juice. Journal of Food Quality, 26, 257-266.

Halliwell, B., \& Whiteman, M. (2004). Measuring reactive species and oxidative damage in vivo and in cell culture: How should you do it and what do the results mean? British Journal of Pharmacology, 142, 231-255. 
Halliwell, B. (2000). Lipid peroxidation, antioxidants and cardiovascular disease: How should we move forward? Cardiovascular Research, 47, 410-418.

Hoelzl, C., Bichler, J., Ferk, F., Simic, T., Nersesyan, A., \& Elbling, L. (2005). Methods for the detection of antioxidants which prevent age related diseases: A critical review with particular emphasis on human intervention studies. Journal of Physiology and Pharmacology, 56, 49-64.

Huang D., Ou, B., \& Prior R.L., (2005). The chemistry behind antioxidant capacity assay. Journal of Agricultural and Food Chemistry, 53, 1841-1856.

Knecht S., Ricklin D., Eberle A.N. \& Ernst B. (2009). Oligohis-Tags: Mechanisms of Binding to $\mathrm{Ni}^{2+}$-NTA Surfaces. Journal of Molecular Recognition, 22: 270-279.

Kurzatkowska K., Mielecki M., Grzelak K., Verwilst P., Dehaen W., Radecki J., Radecka H. (2014). Immobilization of His-tagged kinase JAK2 onto the surface of a plasmon resonance gold disc modified with different copper (II) complexes. Talanta. 2014 Dec; 130:336-41.

Li X., Wang X., Chen D. \& Chen S. (2011). Antioxidant activity and mechanism of protocatechuic acid in vitro. Functional Foods in Health and disease, 7: 232-244.

Marczak E.D., Usui H., Fujita H., Yang Y., Yokoo M., Lipkowski A.W., \& Yoshikawa M. (2003). New antihypertensive peptides isolated from rapeseed. Peptides, 24: 791-798.

Messina J., V. \& Messina. (1991). Increasing use of soyfoods and their potential role in cancer prevention. Journal of the American Dietic Association, 91(7): 836-840.

Myszka DG. (1999). Survey of the 1998 optical biosensor literature. Journal of Molecular Recognition, 12: 390-408.

Mussato I., L.F. Ballesteros, S. Martins \& J.A. Teixeira. (2011). Extraction of antioxidant phenolic compounds from spent coffe grounds. Separation and Purification Technology. 83, 173-179. 
Nieba L., Nieba-Axsmann S.E., Persson A., Hamalainen M., Edebratt F., Hansson A., Lidholm J., Magnusson K., Karlsson A.F., \& Pluckthun A. (1997). Biacore analysis of Histidinetagged proteins using a chelating NTA sensor chip. Analytical Biochemistry, 252: 217-228.

Singleton V.L., J.A. \& Rossi Jr. (1965). Colorimetry of total phenolics with phosphomolybdicphosphotungstic acid reagents, American Journal of Enology and Viticulture. 16, 144-158.

Pan M., Jiang T.S., \& Pan J.L. (2011). Antioxidant Activities of Rapeseed Protein Hydrolysates. Food and Bioprocess Technology, 4: 1144-1152.

Pihlanto-Leppalä, A.. (2001). Bioactive peptides derived from whey proteins: opioid and ACEinhibitory peptides. Trends in Food Science and Technology, 11(9-10): 347-356.

Wong S.-P., Leong, L. P. \& Koh J.H.W. (2006). Antioxidant activities if aqueous extracts if selected plants. Food Chemistry, 99, 775-783.

Wu H-C., Shiau C-Y., Chen H-M. \& Chiou T-K. (2003) Antioxidant Activities of Carnosine, Anserine, Some Free Amino Acids and Their Combination. Journal of Food and Drug Analysis, 11 (2): 148-153.

Xie Z., Huang J., Xu X., \& Jin Z. Antioxidant activity of peptides isolated from alfafa leaf protein hydrolysate, (2008) Food Chemistry 111: 370-376.

Zhang S. B., Wang Z., Xu S. Y. \& Gao X.F. (2009). Purification and characterization of a radical scavenging peptide from rapeseed protein hydrolysates, Journal of American Oil Chemistry Society, 86: 959-966.

Zhang T., Li Y., Miao M., \& Jiang B. (2011). Purification and characterisation of a new antioxidant peptide from chickpea (Cicer aretium L.) protein hydrolysates, Food Chemistry, 128: $28-33$. 
510 Zhang, Mu \& Sun. (2012). Sweet potato protein hydrolysates: antioxidant activity and protective

511 effects on oxidative DNA damage, International Journal of Food Science and Technology, 47: 2304-

512 2310.

513 Zioudrou C., Streaty R.A., \& Klee W.A. (1979) Opioid peptides derived from food proteins.

$514 \quad$ Journal of Biological Chemistry, 10, 254 (7): 2446-2449.

515 


\section{List of Tables and Figures}

518 Table 1. Characterization of hydrolysates: peptide concentration expressed in equivalent glycine,

519 total polyphenol quantification (in mass percentage, w GAE/w hydrolysate powder; GAE: Gallic

520 Acid Equivalent), and respective yields.

521

\begin{tabular}{|c|c|c|c|c|c|c|}
\hline \multirow[b]{2}{*}{ Hydrolysate } & \multicolumn{2}{|c|}{$\begin{array}{r}\text { Peptide concentration } \\
\text { (mM equivalent glycine) }\end{array}$} & \multicolumn{2}{|c|}{$\begin{array}{r}\text { Total polyphenol } \\
\text { quantification in mass \% } \\
(w / w)\end{array}$} & \multicolumn{2}{|c|}{$\begin{array}{r}\text { Yields in fraction collected } \\
\text { after purification }\end{array}$} \\
\hline & $\begin{array}{r}\text { Raw } \\
\text { hydrolysate }\end{array}$ & $\begin{array}{r}\text { Purified } \\
\text { hydrolysate }\end{array}$ & $\begin{array}{r}\text { Raw } \\
\text { hydrolysate }\end{array}$ & $\begin{array}{r}\text { Purified } \\
\text { hydrolysate }\end{array}$ & $\begin{array}{l}\text { Peptide - OPA } \\
\text { quantification }\end{array}$ & $\begin{array}{r}\text { Polyphenol } \\
\text { (Folin-ciocalteu } \\
\text { quantification) }\end{array}$ \\
\hline H1510 & 1.23 & 1.29 & $3.6 \pm 0.2$ & $3.7 \pm 0.2$ & 105 & 103 \\
\hline H1512 & 1.82 & 1.92 & $3.6 \pm 0.2$ & $3.6 \pm 0.4$ & 99 & 99 \\
\hline $\mathrm{H} 4601 \mathrm{~N}$ & 1.38 & 1.74 & $4.6 \pm 0.3$ & $4.1 \pm 0.2$ & 107 & 87 \\
\hline H5603 & 1.50 & 1.74 & $5.9 \pm 0.2$ & $5.5 \pm 0.4$ & 101 & 93 \\
\hline UP Soy & 1.46 & 1.52 & $4.9 \pm 0.3$ & $4.2 \pm 0.0$ & 101 & 86 \\
\hline Hcasein & & & $5.3 \pm 0.2$ & $4.1 \pm 0.3$ & 104 & 82 \\
\hline
\end{tabular}

523

524 
526 Table 2. Dissociation $\left(K_{\mathrm{D}}, \mathrm{mM}\right)$, Affinity constants $\left(K_{\mathrm{A}}, \mathrm{mM}^{-1}\right), \mathrm{R}_{\operatorname{maxc}}$ determined by SPR and

527 metal chelation capacity determined by spectrophotometry. EDTA (EECC) and Carnosine

528 Equivalent Chelation Capacity (CECC) determined for Copper (II) on raw hydrolysate.

\begin{tabular}{|c|c|c|c|c|c|c|c|}
\hline $\begin{array}{l}\text { Nature of the } \\
\text { hydrolysate }\end{array}$ & Sample & $\begin{array}{r}K_{\mathrm{D}}(\mathrm{mM} \\
\text { eq. } \\
\text { Glycine) }\end{array}$ & $\begin{array}{r}K_{\mathrm{A}}\left(\mathrm{mM}^{-1} \text { eq. }\right. \\
\text { glycine })\end{array}$ & $\mathbf{R}_{\operatorname{maxc}}(R U)$ & $\begin{array}{r}\text { Slope of the tangent } \\
\text { at the origin } \\
\text { (Chelated } \mathrm{Cu}^{2+} \% \text { / } \\
\text { molar ratio) }\end{array}$ & $\begin{array}{l}\text { EECC for } \\
\text { copper (II) }\end{array}$ & $\begin{array}{l}\text { CECC for } \\
\text { copper (II) }\end{array}$ \\
\hline Purified & H5603 & 0.90 & 1.11 & 319 & & & \\
\hline \multirow{5}{*}{ Raw } & H1510 & 0.10 & 9.92 & 60 & 91.9 & 2.23 & 3.21 \\
\hline & H1512 & 2.58 & 0.39 & 125 & 56.5 & 1.37 & 1.97 \\
\hline & $\mathrm{H} 4601 \mathrm{~N}$ & 0.78 & 1.29 & 64 & 51.5 & 1.25 & 1.80 \\
\hline & H5603 & 1.04 & 0.96 & 418 & 59.4 & 1.44 & 2.07 \\
\hline & UP Soy & 0.14 & 6.95 & 129 & 69.8 & 1.70 & 2.44 \\
\hline EDTA & & & & & 41.2 & 1 & $T$ \\
\hline Carnosine & & & & & 28.6 & I & 1 \\
\hline
\end{tabular}


531 Figure 1. Sensorgram (down graph) and corresponding sorption isotherm (top graph) of purified

532 (A) and raw (B) H5603 hydrolysate.
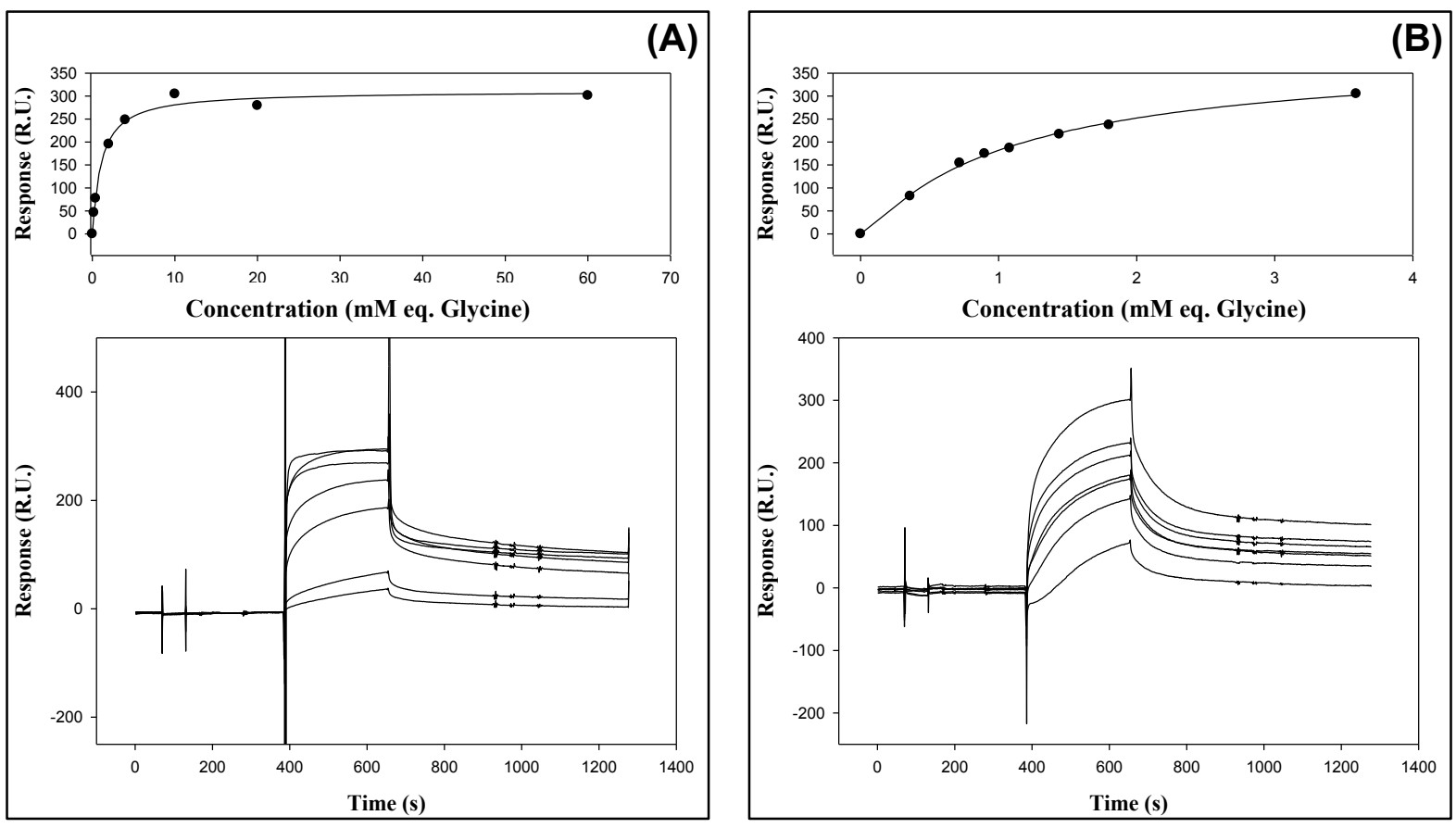
535 Figure 2. Sorption isotherms enabling the determination of the dissociation constant for various

536 raw hydrolysates. Data corrected by the offset and hydrolysate concentration expressed in $\mathrm{mM}$

537 equivalent glycine. Experimental points and their respective fits.

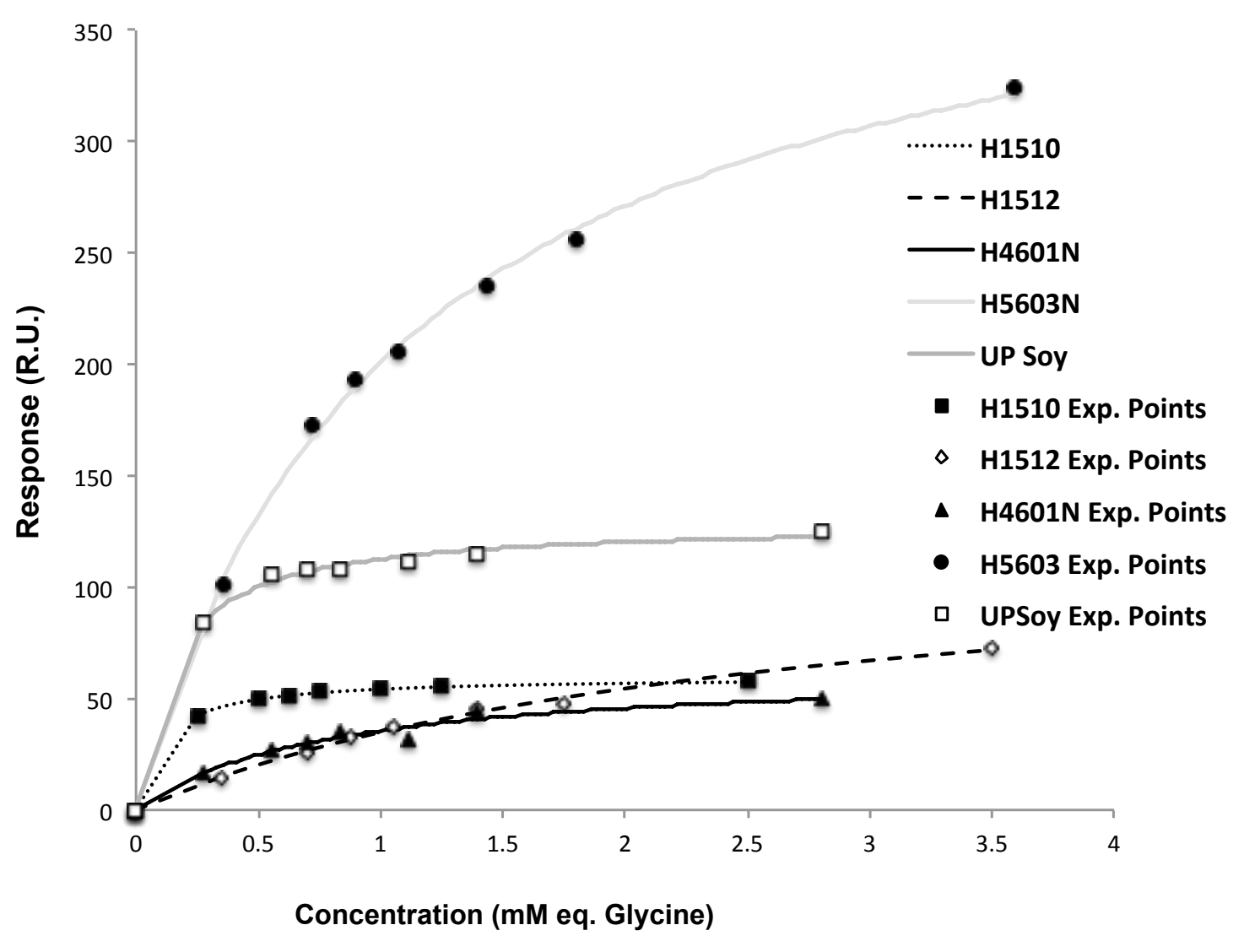


540 Figure 3. Results of metal chelation obtained by spectrophotometry. Panels A and B for EDTA

541 and carnosine. Panels C and D for hydrolysates.
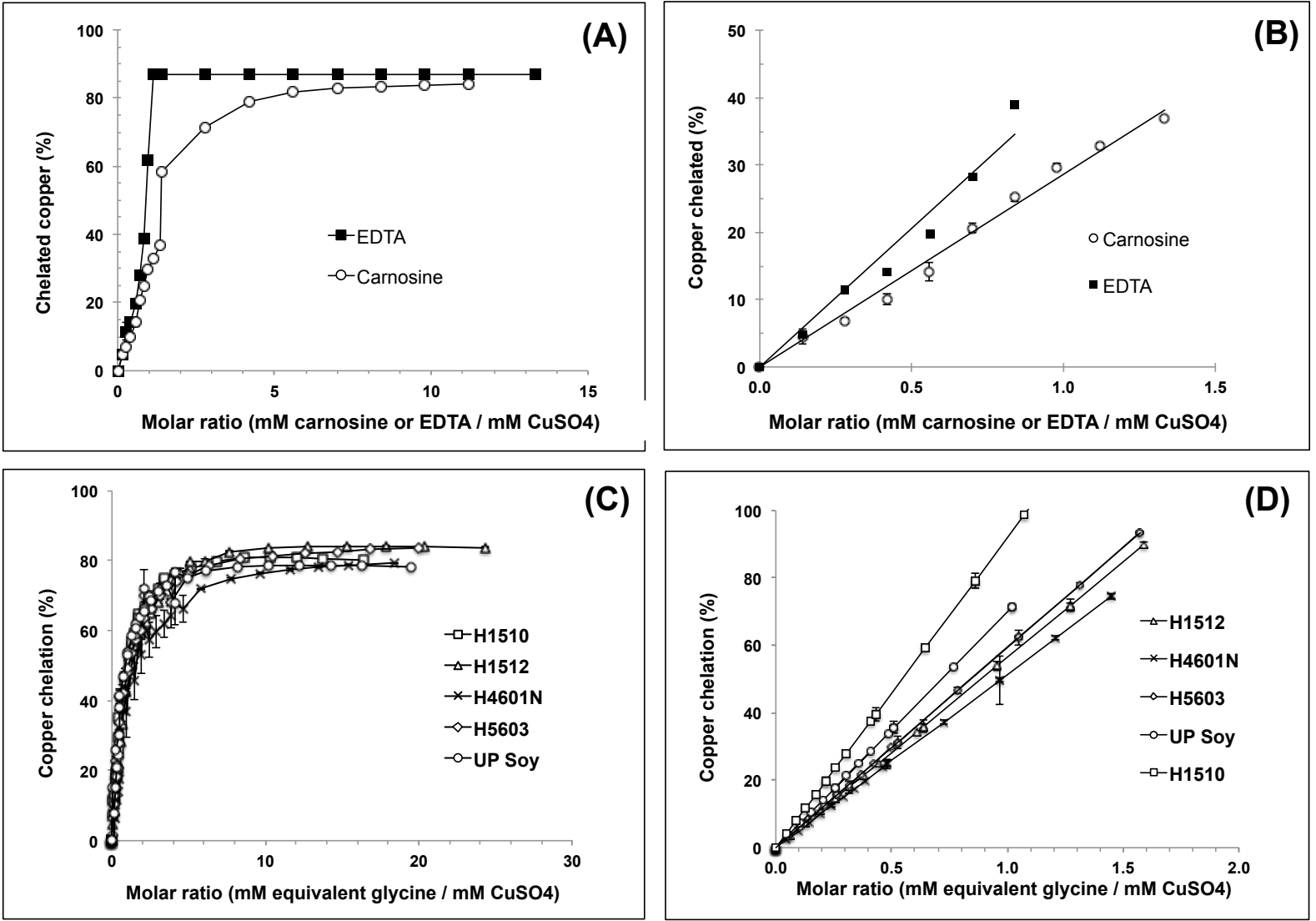
Figure 4. Correlation between affinity constant $\left(K_{\mathrm{A}}, \mathrm{M}^{-1}\right.$ equivalent glycine) and copper (II)

545 chelating activity in raw hydrolysate. (A) Metal chelation expressed as EECC. (B). Metal chelation 546 expressed as CECC.
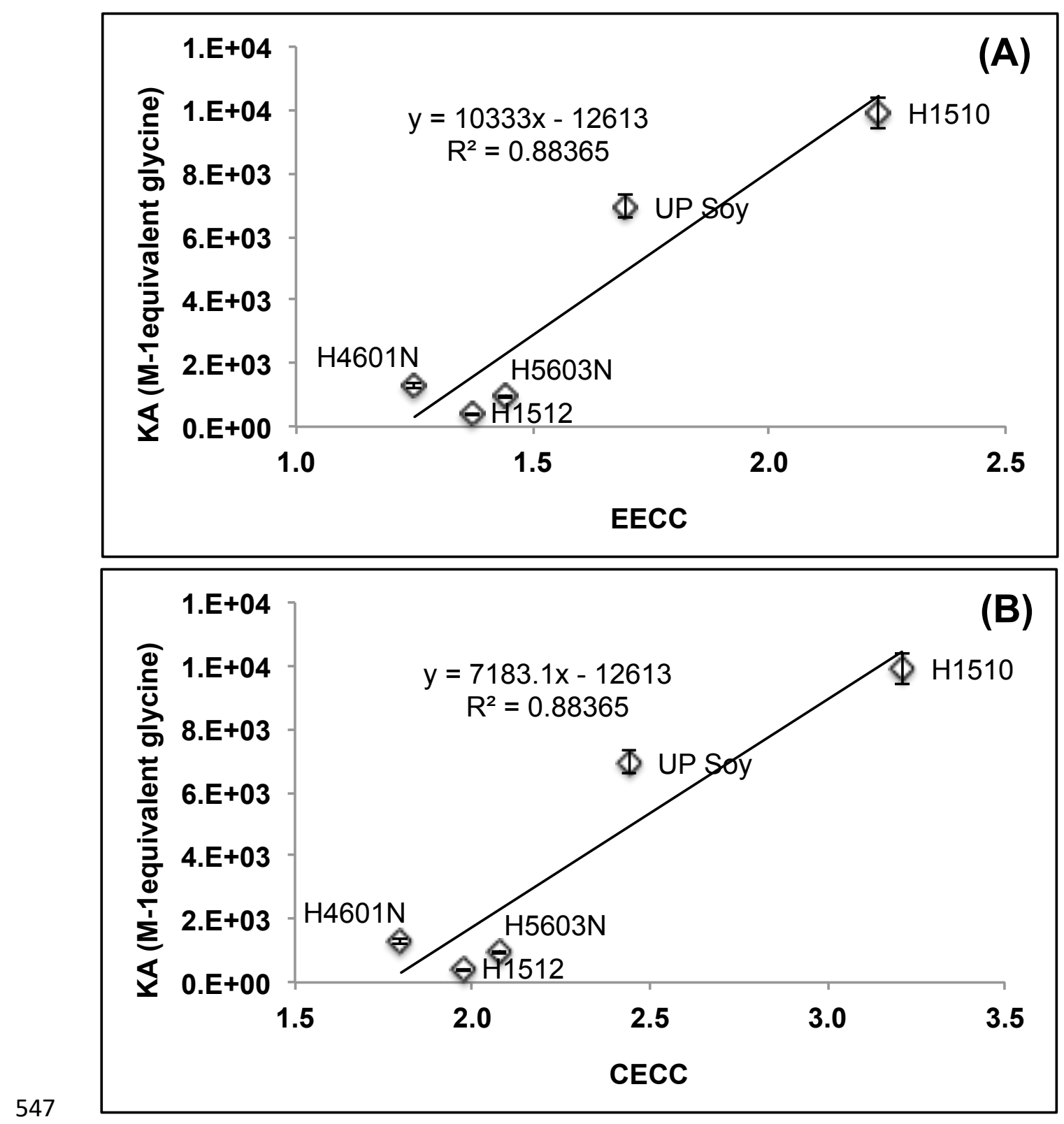

548

549

550 


\section{Supplementary Data}

553 Table SD1. Amino acid composition given in the industrial specification.

\begin{tabular}{|c|c|c|c|c|c|c|}
\hline Characteristics of samples & & 1510 & 1512 & $4610 \mathrm{~N}$ & 5603 & UP Soy \\
\hline \multirow{20}{*}{ Total AA (mg/g) } & Ala & 26.0 & 25.0 & 21.0 & 48.0 & 19.0 \\
\hline & $\mathrm{Arg}$ & 41.0 & 37.0 & 27.0 & 72.0 & 30.0 \\
\hline & Asn & & & & & 0.0 \\
\hline & Asp & 73.0 & 66.0 & 24.0 & & 51.0 \\
\hline & Cys & 4.0 & 3.0 & 11.0 & 8.0 & 0.0 \\
\hline & Gln & & & & & \\
\hline & Glu & 122.0 & 112.0 & 319.0 & & 79.0 \\
\hline & Gly & 25.0 & 24.0 & 27.0 & 37.0 & 13.0 \\
\hline & His & 14.0 & 13.0 & 15.0 & 20.0 & 9.0 \\
\hline & Ile & 23.0 & 22.0 & 32.0 & 34.0 & 19.0 \\
\hline & Leu & 40.0 & 38.0 & 57.0 & 66.0 & 30.0 \\
\hline & Lys & 38.0 & 32.0 & 11.0 & 35.0 & 33.0 \\
\hline & Met & 7.0 & 7.0 & 12.0 & 15.0 & 2.0 \\
\hline & Phe & 26.0 & 24.0 & 46.0 & 43.0 & 20.0 \\
\hline & Pro & 28.0 & 27.0 & 115.0 & 38.0 & 39.0 \\
\hline & Ser & 31.0 & 29.0 & 38.0 & 44.0 & 21.0 \\
\hline & Thr & 24.0 & 22.0 & 21.0 & 31.0 & 17.0 \\
\hline & Trp & & & & & \\
\hline & Tyr & 21.0 & 20.0 & 29.0 & 43.0 & 17.0 \\
\hline & Val & 25.0 & 24.0 & 32.0 & 49.0 & 19.0 \\
\hline \multirow{20}{*}{ Free AA $(\mathrm{mg} / \mathrm{g})$} & Ala & 2.6 & 3.8 & 1.9 & 0.6 & 5.6 \\
\hline & Arg & 9.2 & 9.8 & 8.6 & 1.0 & 9.9 \\
\hline & Asn & & 2.4 & 1.8 & 0.9 & 4.0 \\
\hline & Asp & 2.1 & 3.1 & 0.7 & 0.4 & 5.1 \\
\hline & Cys & & & & 2.9 & 0.1 \\
\hline & Gin & 3.5 & 0.2 & 1.2 & 0.4 & \\
\hline & Glu & & 5.2 & 0.4 & 2.9 & 6.9 \\
\hline & Gly & 2.5 & 3.6 & 1.0 & 0.1 & 1.1 \\
\hline & His & 1.4 & 1.3 & 3.2 & 0.1 & 2.6 \\
\hline & lle & 0.5 & 1.6 & 4.8 & 0.2 & 4.8 \\
\hline & Leu & 6.3 & 11.0 & 10.7 & 1.9 & 13.9 \\
\hline & Lys & 4.6 & 6.4 & 2.3 & 0.6 & 10.8 \\
\hline & Met & 0.9 & 1.7 & 2.0 & 0.2 & 1.3 \\
\hline & Phe & 2.7 & 4.4 & 4.9 & 1.4 & 7.7 \\
\hline & Pro & & 0.3 & 0.5 & 0.3 & 0.6 \\
\hline & Ser & 4.0 & 4.9 & 3.9 & 1.1 & 5.4 \\
\hline & Thr & 1.7 & 2.2 & 5.7 & 0.3 & 4.8 \\
\hline & Trp & 1.5 & 2.5 & 3.0 & & 4.5 \\
\hline & Tyr & 1.1 & 1.6 & 1.3 & 0.1 & 1.7 \\
\hline & Val & 1.0 & 2.0 & 5.0 & 0.1 & 5.0 \\
\hline
\end{tabular}


556 Table SD2. Global composition in amino acids (AA; $\mathrm{mg} / \mathrm{g}$ ) by class and main characteristics of

557 the studied hydrolysates. TN: Total Nitrogen (\%). DH: ratio AN/TN x 100.

\begin{tabular}{|c|c|c|c|c|c|c|}
\hline & & 1510 & 1512 & $4610 \mathrm{~N}$ & 5603 & UP Soy \\
\hline \multicolumn{7}{|c|}{ Global amino-acid (AA) composition ( $\mathrm{mg} / \mathrm{g}$ ) } \\
\hline \multirow[t]{2}{*}{ Positively charged AA (RHK) } & Total & 93 & 82 & 53 & 127 & 72 \\
\hline & Free & 15 & 18 & 14 & 2 & 23 \\
\hline \multirow[t]{2}{*}{ Negatively charged AA (DE) } & Total & 195 & 178 & 343 & 0 & 130 \\
\hline & Free & 2 & 8 & 1 & 3 & 12 \\
\hline \multirow[t]{2}{*}{ Polar uncharged AA (STNQ) } & Total & 55 & 51 & 59 & 75 & 38 \\
\hline & Free & 9 & 10 & 13 & 3 & 14 \\
\hline \multirow[t]{2}{*}{ Sulfured AA (CM) } & Total & 11 & 10 & 23 & 23 & 2 \\
\hline & Free & 1 & 2 & 2 & 3 & 1 \\
\hline \multirow[t]{2}{*}{ Hydrophobic AA (AVILMFYW) } & Total & 168 & 160 & 229 & 298 & 126 \\
\hline & Free & 17 & 29 & 34 & 5 & 45 \\
\hline \multirow[t]{2}{*}{ Aromatic AA (FYW) } & Total & 47 & 44 & 75 & 86 & 37 \\
\hline & Free & 5 & 9 & 9 & 2 & 14 \\
\hline \multicolumn{7}{|l|}{ Other parameters } \\
\hline \multicolumn{2}{|l|}{ Total Nitrogen (TN, \%) } & 9.2 & 8.8 & 14.2 & 12.8 & 8.0 \\
\hline \multicolumn{2}{|l|}{$\mathrm{DH}$ (ratio AN/TN x100) } & $16-29$ & 27.5 & 15.4 & $14-22$ & $25-35$ \\
\hline \multicolumn{2}{|c|}{ DH (ratio AN/TN x100), mean value } & 22.5 & 27.5 & 15.4 & 18.0 & 30.0 \\
\hline
\end{tabular}


560 Table SD3. Mini-review on copper chelation tests carried out on peptides and on hydrolysate in

561 the literature and their experimental conditions.

\begin{tabular}{|c|c|c|c|c|c|c|c|}
\hline & $\begin{array}{r}\text { Wu et al, } \\
2003\end{array}$ & $\begin{array}{r}\text { Saiga et al, } \\
2003\end{array}$ & $\begin{array}{r}\text { Carasco- } \\
\text { Castilla et al, } \\
2012 \\
\end{array}$ & $\begin{array}{r}\text { Carasco- } \\
\text { Castilla et al, } \\
2012 b \\
\end{array}$ & $\begin{array}{r}\text { Guo et al, } \\
2015\end{array}$ & $\begin{array}{r}\text { Torres- } \\
\text { Fuentes et al, } \\
2011 \\
\end{array}$ & $\begin{array}{r}\text { Zhang et al, } \\
2011\end{array}$ \\
\hline Sample nature & Peptides & Hydrolysate & Hydrolysate & $\begin{array}{r}\text { Hydrolysate } \\
\text { and peptide } \\
\text { fraction }\end{array}$ & $\begin{array}{r}\text { Peptide } \\
\text { hydrolysate }\end{array}$ & $\begin{array}{r}\text { Chickpea } \\
\text { protein } \\
\text { hydrolysate }\end{array}$ & Hydrolysate \\
\hline $\begin{array}{l}\text { Range of concentration, } \\
\text { volume sample }\end{array}$ & $\begin{array}{r}0.5-40 \mathrm{mM}, 2 \\
\mathrm{~mL}\end{array}$ & & $100 \mu \mathrm{g}$ & $\begin{array}{r}100 \mu \mathrm{g} \text { for } \\
\text { hydrolysate or } \\
50 \mu \mathrm{g} \text { for } \\
\text { peptide }\end{array}$ & $\begin{array}{r}\text { Sample, } 100 \\
\mu \mathrm{g} / \mathrm{mL}, 200 \\
\mu \mathrm{L}\end{array}$ & n.d. & $1 \mathrm{~mL}$ \\
\hline Method adapted from & $\begin{array}{r}\text { Shimada et al, } \\
1992\end{array}$ & & $\begin{array}{r}\text { Saiga et al, } \\
2003\end{array}$ & $\begin{array}{r}\text { Saiga et al, } \\
2003\end{array}$ & $\begin{array}{r}\text { Saiga et al, } \\
2003\end{array}$ & $\begin{array}{r}\text { Saiga et al, } \\
2003\end{array}$ & $\begin{array}{r}\text { Kong and } \\
\text { Xiong, } 2006\end{array}$ \\
\hline Positive control & n.d. & $\begin{array}{l}\text { EDTA at } \\
0.045 \%\end{array}$ & n.d. & n.d. & $\mathrm{CPPS}^{* * *}$ & n.d. & n.d. \\
\hline Negative control (blank) & $\begin{array}{r}\text { Deionized } \\
\text { water, treated } \\
\text { with reverse } \\
\text { osmosis }\end{array}$ & & n.d. & n.d. & Deionized ater & n.d. & n.d. \\
\hline Buffer & $\begin{array}{r}\text { Hexamine } \\
\text { buffer (10 } \\
\mathrm{mM}), \mathrm{KCl}(10 \\
\mathrm{mM})\end{array}$ & & $\begin{array}{r}\text { Na acetate } \\
\text { buffer, } 50 \mathrm{mM} \text {, } \\
290 \mu \mathrm{L}\end{array}$ & $\begin{array}{r}\text { Na acetate } \\
\text { buffer, } 50 \mathrm{mM}, \\
290 \mu \mathrm{L}\end{array}$ & $\begin{array}{r}\mathrm{Na} \text { acetate } \\
\text { buffer, } 50 \mathrm{mM} \text {, }\end{array}$ & $\begin{array}{r}\mathrm{Na} \text { acetate } \\
\text { buffer, } 50 \mathrm{mM},\end{array}$ & $\begin{array}{r}\text { Pyridine, } 10 \%, \\
1 \mathrm{~mL}\end{array}$ \\
\hline
\end{tabular}

$\begin{array}{lllll}\text { pH ajusted } & \text { No } & \text { pH } 6.0 & \text { pH } 5.0 & \text { pH } 6.0\end{array}$

\begin{tabular}{|c|c|c|c|c|c|c|c|}
\hline $\begin{array}{l}\text { Copper source and } \\
\text { concentration }\end{array}$ & $\begin{array}{r}\mathrm{CuSO}_{4}, 3 \mathrm{mM}, \\
2 \mathrm{~mL}\end{array}$ & $\begin{array}{r}\mathrm{CuSO}_{4}, 2 \mathrm{mM} \text {, } \\
1 \mathrm{~mL} ; \text { mixed } \\
\text { with pyridine } \\
(\mathrm{pH} 7.0)\end{array}$ & $\begin{array}{r}\mathrm{CuSO}_{4} \cdot 5 \mathrm{H}_{2} 0 \\
1 \mu \mathrm{g}\end{array}$ & $\begin{array}{r}\mathrm{CuSO}_{4} .5 \mathrm{H}_{2} 0 \\
10 \mu \mathrm{g}\end{array}$ & $\begin{array}{r}\mathrm{CuSO}_{4}, 1 \\
\mathrm{mg} / \mathrm{mL}, 20 \mu \mathrm{L}\end{array}$ & $\begin{array}{r}\mathrm{CuSO}_{4}, 0.1 \\
\mu \mathrm{g} / \mu \mathrm{L}, 100 \mu \mathrm{L}\end{array}$ & $\begin{array}{r}\mathrm{CuSO}_{4}, 2 \mathrm{mM}, \\
1 \mathrm{~mL}\end{array}$ \\
\hline $\begin{array}{l}\text { Metal chelating indicator, } \\
\text { concentration, volume }\end{array}$ & $\begin{array}{r}\text { TMM }^{*}, 1 \mathrm{mM}, \\
0.2 \mathrm{~mL}\end{array}$ & $\mathrm{PV}^{* *}, 20 \mu \mathrm{L}$ & $\begin{array}{r}\mathrm{PV}^{* *}, 4 \mathrm{mM}, 6 \\
\mu \mathrm{L}\end{array}$ & $\begin{array}{r}\mathrm{PV}^{* *}, 4 \mathrm{mM}, 6 \\
\mu \mathrm{L}\end{array}$ & $\begin{array}{r}\mathrm{PV}^{* *}, 2 \mathrm{mM}, \\
10 \mu \mathrm{L}\end{array}$ & $\begin{array}{r}\mathrm{PV}^{* *}, 4 \mathrm{mM}, \\
25 \mu \mathrm{L}\end{array}$ & $\begin{array}{r}\mathrm{PV}^{* *} 0.1 \%, 20 \\
\mu \mathrm{L}\end{array}$ \\
\hline $\begin{array}{l}\text { Incubation: time, } \\
\text { temperature }\end{array}$ & $3 \mathrm{~min}, \mathrm{RT}$ & & & & $5 \mathrm{~min}, 37^{\circ} \mathrm{C}$ & & \\
\hline Wavelength (s) & $485 \mathrm{~nm}$ & $632 \mathrm{~nm}$ & $632 \mathrm{~nm}$ & $632 \mathrm{~nm}$ & $632 \mathrm{~nm}$ & $632 \mathrm{~nm}$ & $632 \mathrm{~nm}$ \\
\hline $\mathrm{Cu}^{2+}$ chelating ability (\%) & $\begin{array}{r}\left(\left(A_{0^{-}}\right.\right. \\
\left.\left.A_{s}\right) / A_{0}\right) \times 100 \\
\end{array}$ & & $\begin{array}{r}\left(\left(A_{0^{-}}\right.\right. \\
\left.\left.A_{s}\right) / A_{0}\right) \times 100 \\
\end{array}$ & $\begin{array}{r}\left(\left(A_{0^{-}}\right.\right. \\
\left.\left.A_{s}\right) / A_{0}\right) \times 100 \\
\end{array}$ & & $\begin{array}{r}(1- \\
\left.\left(A_{s} / A_{0}\right)\right) \times 100 \\
\end{array}$ & $\begin{array}{r}(1- \\
\left.\left(A_{s} / A_{0}\right)\right) \times 100 \\
\end{array}$ \\
\hline Standard curve & n.d. & & n.d. & n.d. & n.d. & n.d. & n.d. \\
\hline Scale & Cuvette & & $\begin{array}{l}\text { Microplate } \\
\text { reader }\end{array}$ & $\begin{array}{l}\text { Microplate } \\
\text { reader }\end{array}$ & $\begin{array}{r}\text { Microplate } \\
\text { reader }\end{array}$ & n.d. & $\overline{\text { Cuvette }}$ \\
\hline
\end{tabular}

* TetraMethylMurexide

** Pyrocatechol Violet

CPPs:

CaseinoPhosphoPeptides

n.d.: not determined 
564 Table SD4. Amino acids and their functional group involved in metal chelation.

565

\begin{tabular}{|c|c|c|c|c|c|c|}
\hline Aminoacid & Group involved & Atom involved & $\mathrm{pK}_{\mathrm{a}}$ & $\mathbf{p K}_{\mathrm{b}}$ & $\mathrm{pK}_{\mathrm{R}}$ & Reference \\
\hline Aspartic acid & \multirow{5}{*}{ Carboxylate } & \multirow{5}{*}{ Oxygen rich group } & 2.09 & 9.82 & 3.86 & Zacchariou and Hearn, 1996 \\
\hline \multirow[t]{4}{*}{ Glutamic acid } & & & 2.19 & 9.67 & 4.25 & Lv et al, 2009 \\
\hline & & & & & & Bamdad and Chen, 2013 \\
\hline & & & & & & Zhang et al, 2009 \\
\hline & & & & & & Gerbino et al, 2011 \\
\hline \multirow{4}{*}{ Histidine } & \multirow{4}{*}{ Imidazole } & \multirow{4}{*}{ Nitrogen rich group } & \multirow{4}{*}{1.82} & \multirow{4}{*}{9.17} & \multirow{4}{*}{6.00} & Zacchariou and Hearn, 1996 \\
\hline & & & & & & Zoroddhu et al, 2009 \\
\hline & & & & & & Lv et al, 2009 \\
\hline & & & & & & Wu et al, 2003 \\
\hline Arginine & \multirow{2}{*}{ Amino group } & \multirow{2}{*}{ Nitrogen } & 2.17 & 9.04 & 12.48 & Farvin et al, 2010 \\
\hline Lysine & & & 2.18 & 8.95 & 10.53 & Zhang et al, 2009 \\
\hline Cystein & Thiol & Sulfur & 1.71 & 8.33 & 10.78 & Lv et al, 2009 \\
\hline Serine & \multirow{5}{*}{ Hydroxyl } & \multirow{5}{*}{ Oxygen } & 2.21 & 9.15 & & Lv et al, 2009 \\
\hline \multirow[t]{4}{*}{ Threonine } & & & 2.63 & 10.43 & & Bamdad and Chen, 2013 \\
\hline & & & & & & Storckdieck et al, 2007 \\
\hline & & & & & & Swain et al, 2002 \\
\hline & & & & & & Taylor and Layrisse, 1986 \\
\hline Glycine & \multirow{2}{*}{ n.d. } & \multirow{2}{*}{ n.d. } & 2.34 & 9.60 & & \multirow{2}{*}{ Wu et al, 2003} \\
\hline Alanine & & & 2.35 & 9.69 & & \\
\hline
\end{tabular}

567 
Figure SD1. OPA quantification test carried out on raw hydrolysate powder $(1 \mathrm{~g} / \mathrm{L})$ and on

569 powder of hydrolysate purified onto CC6 polyamide column, lyophilised and reconstituted $570(1 \mathrm{~g} / \mathrm{L})$.

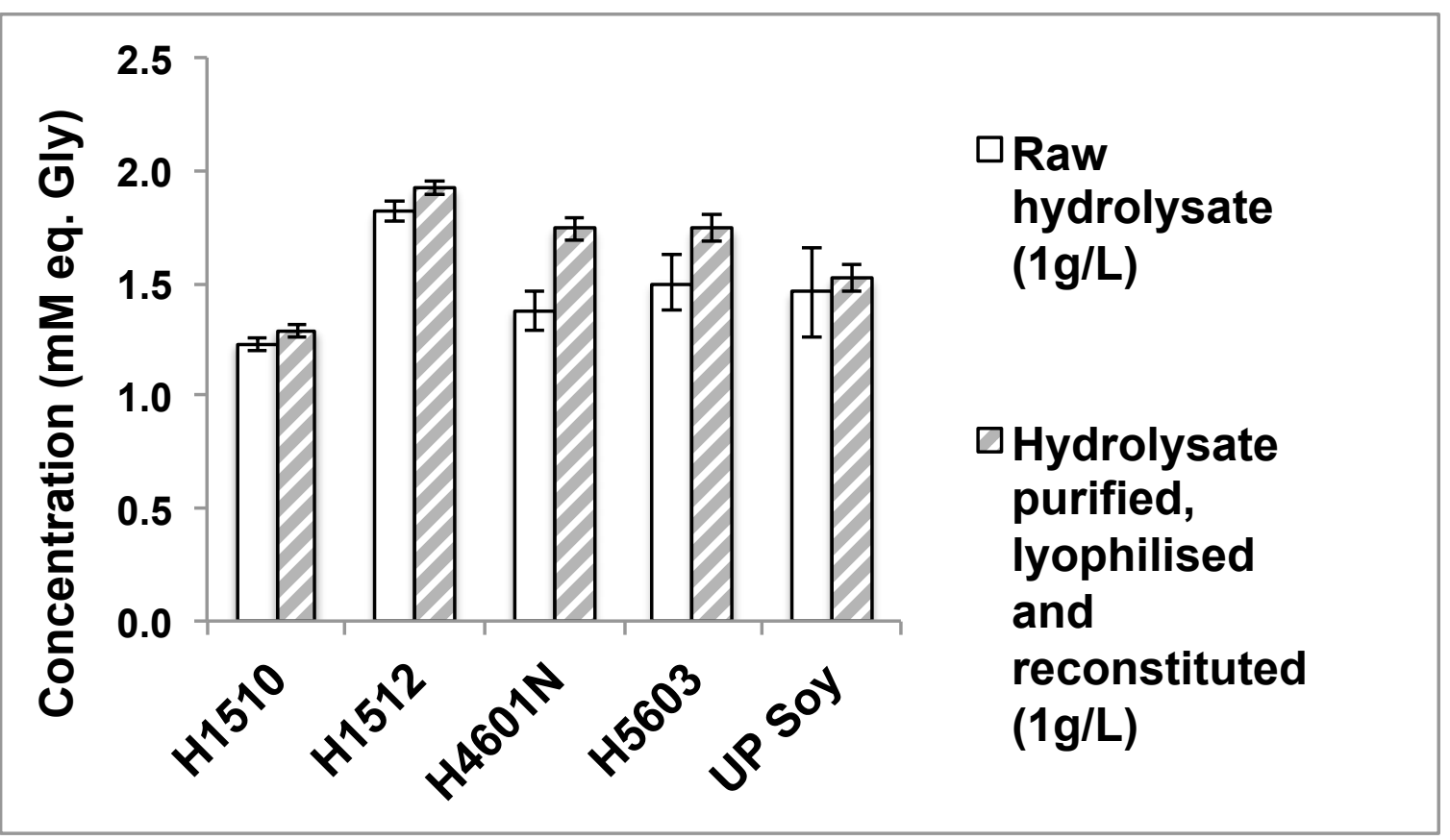

572 